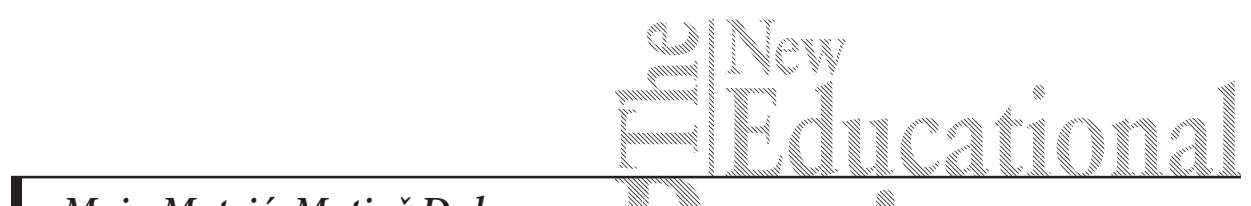

Maja Matrić, Matjaž Duh

Slovenia

\title{
Creativity among Gifted and Non-Gifted Students
}

DOI: $10.15804 /$ tner.2015.40.2.21

\begin{abstract}
An overview of the literature on gifted students suggests that students can be gifted by showing intelligence and/or creative abilities. Whether teachers are able to recognize intelligent and/or creative students is a matter of being skilled and can have a tremendous impact on students' course of education. In out study, we included students of Slovenian primary schools who were either recognized as gifted or non-gifted by their teachers. To find out what differences occur in the creativity levels of gifted and non-gifted students, their creativity levels were recorded using the LV1Test, measuring their artistic-creative and artistic-appreciative abilities. Data analysis reveals that the gifted students were more successful in gaining a higher average score on the test, as well as the majority of individual items in the test.
\end{abstract}

Keywords: creativity, gifted, non-gifted, gender, elementary school, primary school

\section{Introduction}

Even though the roots of the concept of creativity reach far into the $20^{\text {th }}$ century, it is still very much present in contemporary pedagogical research. Creativity is a complex concept, which is evident from various definitions we are offered by the relevant literature (Mumford, Mobley, Uhlman, Reiter-Palmon and Doares, 1991; Robinson, 2001; Sefton-Green and Sinker, 2000; Torrance, 1977). Koestler (1964) perceived it as the ability to connect previously unconnected ideas and the production of outcome, hence emphasizing the cognitive aspect. Other authors, emphasizing the thought-action aspect, describe it as the ability to produce new, creative ideas (Hitt, 1965; Newell and Shaw, 1972), while others see it as using the 
existing knowledge to find creative solutions, however maintaining that the new solution must have value (Higgins, 1999; Jurman, 2004). Borden (1998) added the aspect of motivation and emotion to the generation of new ideas, linking it to cultural context and personality.

The importance of environment in boosting creativity was extensively stressed by Feldhusen and Hoover (2006), who claim that creativity results from the environment which places emphasis on academic growth on the basis of talent. It is not surprising that a growing number of countries strive towards incorporating creativity into their educational curriculums (Sharp and Le Métais, 2000; Craft, 2005; Davies, 2006; Stables, 2009). A creative learning environment, consisting of both the physical and pedagogic environment, is therefore supposed to be a place of knowledge, ownership, relevance and innovation (Jeffrey, 2006). Duh (2004) stresses the importance of creativity in children's environment, claiming that a creative atmosphere inspires students towards spontaneous work, adding that it is teachers' job to help develop children's creative joy by means of creative tasks and didactic tools. Juriševič (2011) points out that teachers can acquire additional competences in various programmes of in-service teacher training in order to deepen their knowledge of work with gifted students. Fryer (2009) also discovered that teachers' willingness to develop creativity differed mostly in variables related to teachers' ability to take students' needs into consideration. Recent research on teachers' and students' perceptions of needs satisfaction in the Slovenian environment revealed consistent discrepancies across subject areas (Matrić and Košir, 2014). Namely, the teachers believed they were satisfying the students' need for autonomy at a higher level than the students reported.However, Dawson (1995) reveals that teachers often place little value on creative behaviours of their students, although they do generally claim to value creativity in their students. However, in art education, creativity can only be achieved through the implementation of productive and receptive art activities (Duh and Korošec-Bowen, 2014).

\section{Creativity, intelligence and giftedness}

Research reveals low correlations between IQ and creativity. Namely, even though creative thinking tends to be more frequent in children with a high IQ, IQ itself does not suffice, resulting in low creativity capacities in children with high IQs or their disinclination to use their imagination (Guilford and Christiansen, 1973; Torrance, 1980; Getzels and Jackson, 1962; Wallach and Kogan, 1965). Therefore, a high IQ does not forecast creative skills and, yet, creative thinking 
occurs more often in highly intelligent individuals. With this in mind, Torrance (1959) revealed that when using traditional IQ tests, 70\% of individuals with the highest $20 \%$ of scores on creativity tests would be missed. To more specifically establish the role of IQ in creativity, Terman and Oden (1947) paired an IQ test with a test of creative ability to show that high-IQ participants were more productive in arts and sciences than their average-IQ counterparts. Yamamoto (1964, as cited in Ulmann, 1968) proved that, apart from these two groups recognized by Getzes and Jackson, there are other students who are extremely intelligent and creative. Flescher (1963, as cited in Ulmann, 1968) identifies yet another group of students, characterized as neither creative nor intelligent. These results show that all four combinations of intelligence and creativity are possible and they overlap with the results of Hitt (1965), who states that all four combinations occur in logical (convergent) and original (divergent) thinking. However, later research (Houtz, Rosenfield and Tetenbaum, 1978) showed that gifted students, whom Gagné (1991) described as having above-average abilities, such as intellectual or creative aptitude, did not generally achieve high scores in creativity tests as their results showed great individual differences. Their findings were in accordance with previous research on gifted students in terms of intelligence and creativity.

\section{The presented study}

The research was aimed at recording artistic-creative abilities and artisticappreciative abilities among $8^{\text {th }}$-grade and $9^{\text {th }}$ - grade students of elementary schools in the Posavje region, Slovenia. To do so, the students were given a test measuring their artistic-creative abilities and artistic-appreciative abilities.

The specific research questions were:

(1) What are the general levels of creativity and what gender differences occur (RQ1)?

(2) What are the levels of creativity of gifted students and what gender differences occur (RQ2)?

(3) What are the levels of creativity of non-gifted students and what gender differences occur (RQ3)?

(4) What differences in creativity levels occur among gifted students according to different types of giftedness they were ascribed to by their teachers (RQ4)?

(5) What differences in creativity levels occur among gifted students according to visual art giftedness they were ascribed to by their teachers (RQ5)? 


\section{Methods}

\section{Participants}

The sample was composed of 35 students ( $51.4 \%$ female) attending the $8^{\text {th }}$ $(65.7 \%)$ and $9^{\text {th }}(34.3 \%)$ grades of elementary schools from the Posavje region, Slovenia. Out of the 35 students, 12 (34.3\%) were gifted (58.3\% female).

Table 1. School demographic information

\begin{tabular}{lccccccc}
\hline & $\mathrm{N}$ & $\begin{array}{c}\text { Male } \\
\%\end{array}$ & $\begin{array}{c}\text { Female } \\
\%\end{array}$ & $\begin{array}{c}\text { Gifted } \\
\text { male } \\
\%\end{array}$ & $\begin{array}{c}\text { Gifted } \\
\text { female } \\
\%\end{array}$ & $\begin{array}{c}\text { Non-gifted } \\
\text { male } \\
\%\end{array}$ & $\begin{array}{c}\text { Non-gifted } \\
\text { female } \\
\%\end{array}$ \\
\hline $8^{\text {th }}$ grade & 23 & 47.8 & 52.2 & 50.0 & 50.0 & 46.7 & 53.3 \\
\hline $9^{\text {th }}$ grade & 12 & 50.0 & 50.0 & 25.0 & 75.0 & 62.5 & 37.5 \\
\hline Gifted & 12 & 41.7 & 58.3 & & & & \\
\hline Non-gifted & 23 & 52.2 & 47.8 & & & & \\
\hline
\end{tabular}

According to the type of giftedness, 50\% of the students achieved the highest score on the general intellectual scale ( $16.7 \%$ female), $25 \%$ on the specific academic scale $(0 \%$ female), $0 \%$ on the creativity scale, $25 \%$ on the leadership scale $(8.3 \%$ female), $16.7 \%$ on the psychomotor scale ( $0 \%$ female), $16.7 \%$ on the technical scale ( $0 \%$ female), $33.3 \%$ on the literary scale ( $33.3 \%$ female), $16.7 \%$ on the drama scale (16.7.\% female), $8.3 \%$ on the musical arts scale ( $8.3 \%$ female) and $58.3 \%$ on the art scale (33.4\% female).

Table 2. Gifted students according to the type of giftedness

\begin{tabular}{lccclccc}
\hline Type of giftedness & $\mathrm{N}$ & $\begin{array}{c}\text { Male } \\
\%\end{array}$ & $\begin{array}{c}\text { Female } \\
\%\end{array}$ & Type of giftedness & $\mathrm{N}$ & $\begin{array}{c}\text { Male } \\
\%\end{array}$ & $\begin{array}{c}\text { Female } \\
\%\end{array}$ \\
\hline General intellectual & 6 & 67.7 & 33.3 & Technical & 2 & 100 & 0 \\
\hline Specific academic & 3 & 100 & 0 & Literary & 4 & 0 & 100 \\
\hline Creative & 0 & 0 & 0 & Drama & 2 & 0 & 100 \\
\hline Leadership & 3 & 67.7 & 33.3 & Music & 1 & 0 & 100 \\
\hline Psychomotor & 2 & 100 & 0 & Art & 7 & 42.9 & 57.1 \\
\hline
\end{tabular}

\section{Procedure}

Prior to administering the LV1 Test questionnaire, the parents were asked to sign permission, allowing their children to take the LV1Test, as well as the school counsellor to provide us with the giftedness assessment scales for each gifted student. The students completed the LV1 Test after lessons under the supervi- 
sion of the researcher. The students responded anonymously, with the exception of the gifted students, whose identity was known in order to enable us to make a comparison of their LV1 test results and their score on the giftedness assessment scales. The scales were provided by the school counsellors who organize the work with the gifted students at particular elementary schools in the Slovenian Posavje region.

\section{Measures}

For the purpose of measuring the artistic-creative and artistic-appreciative abilities, the LV1Test was used (Duh, 2004). The test consists of two parts. The first part contains six tasks and measures students' artistic-creative development. The tasks require from students to complete a drawing or draw an artistic sign. Individual tasks represent one of the aspects of artistic-creative development, namely flexibility $(\mathrm{Fx})$, fluency $(\mathrm{Fl})$, originality (Or), redefinition $(\mathrm{Re})$, sensitivity to visual problems (sp) and elaboration (El). A student is awarded between 0 and 6 points for each task- a total of 36 points. The second part of the test measures students' artistic-appreciative abilities and consists of eight multiple choice questions. The second part of the test is divided into two groups: the first (questions 7-10) measures students' perceptive abilities, while the second (questions 11-13) measures students' receptive skills and question 14 their artistic knowledge. A student is awarded 2, 3 or 4 points for individual question - a total of 26 points. The questions in this part were about Paul Cezanne's painting "The blue vase", therefore each student was provided with a quality printed reproduction of the painting. The test included questions, such as: (7 P1) Which is the most important object in the painting?; (8 P2) Which two colours are the most important in the painting?; (9 P3) In which part of the painting are the colours the strongest?; (10 P4) Is there anything you would add to the painting?; (11 R1) What in the painting caught your attention the most?; (12 R2) The beauty and freshness of the flowers give the impression of...; (13 R3) How would you feel in the room with the vase?; (14 K) What are the basic artistic means in the painting?, etc. The authors of the instrument based the LV1Test on previously validated instruments used to measure the artistic-creative and artistic-appreciative development of children and their perceptive and receptive skills (Karlavaris and Kraguljac, 1970; Berce-Golob, 1990; Duh, 2004; Duh, Čagran and Huzjak, 2012; Duh, Zupančič and Čagran, 2014). For the purpose of the research, an additional measure was used. Namely, the assessment scale of each gifted student, completed by their teachers in the process of the nomination of a gifted student (Žagar, Artač, Bezič, Nagy in Purgaj, 1999). 


\section{Results and interpretation}

\section{General levels of creativity}

In this research, we were particularly interested in all the students' art creativity and art appreciation tests. Furthermore, we aimed at discovering any gender differences that might occur. The results can be seen in Table 3 .

Table 3. Means and standard deviations of general creativity levels $(\mathrm{N}=35)$

\begin{tabular}{|c|c|c|c|c|c|c|c|}
\hline & Item & $\begin{array}{c}\text { Means } \\
\text { all } \\
(N=35)\end{array}$ & $\begin{array}{c}\text { Standard } \\
\text { deviation } \\
\text { all }\end{array}$ & $\begin{array}{c}\text { Means } \\
\text { boys } \\
(N=17)\end{array}$ & $\begin{array}{c}\text { Standard } \\
\text { deviation } \\
\text { boys }\end{array}$ & $\begin{array}{c}\text { Means } \\
\text { girls } \\
(N=18)\end{array}$ & $\begin{array}{c}\text { Standard } \\
\text { deviation } \\
\text { girls }\end{array}$ \\
\hline & & $M$ & $S D$ & $M$ & $S D$ & $M$ & $S D$ \\
\hline \multirow{7}{*}{ 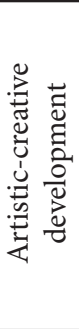 } & 1. $\mathrm{Fx}$ & 1.40 & 1.56 & 1.24 & 1.48 & 1.56 & 1.65 \\
\hline & 2. $\mathrm{Fl}$ & 4.49 & 2.02 & 4.35 & 2.12 & 4.61 & 1.97 \\
\hline & 3. Or & 1.37 & 0.73 & 1.35 & 0.79 & 1.39 & 0.70 \\
\hline & 4. $\operatorname{Re}$ & 0.71 & 1.02 & 0.53 & 1.01 & 0.89 & 1.02 \\
\hline & 5. Sp & 1.86 & 1.14 & 1.59 & 1.00 & 2.11 & 1.23 \\
\hline & 6. El & 3.69 & 1.28 & 3.00 & 1.46 & 4.33 & 0.59 \\
\hline & 7.P1 & 2.63 & 0.77 & 2.76 & 0.66 & 2.50 & 0.86 \\
\hline \multirow{8}{*}{ 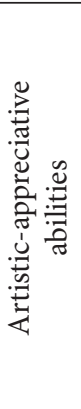 } & 8. P2 & 1.71 & 0.57 & 1.59 & 0.62 & 1.83 & 0.51 \\
\hline & 9. P3 & 2.94 & 1.49 & 3.12 & 1.41 & 2.78 & 1.59 \\
\hline & 10. P4 & 1.89 & 1.75 & 1.71 & 1.69 & 2.06 & 1.83 \\
\hline & 11. R1 & 2.14 & 1.19 & 2.00 & 1.27 & 2.28 & 1.13 \\
\hline & 12. R2 & 0.94 & 1.41 & 1.24 & 1.52 & 0.67 & 1.28 \\
\hline & 13. R3 & 2.51 & 1.01 & 2.53 & 1.07 & 2.50 & 0.99 \\
\hline & 14. K & 1.97 & 1.44 & 1.76 & 1.52 & 2.17 & 1.38 \\
\hline & $\begin{array}{c}\text { Group } \\
\text { average }\end{array}$ & 2.16 & 1.24 & 2.05 & 1.26 & 2.26 & 1.20 \\
\hline
\end{tabular}

In Table 3, analysis of the LV1Test includes the results of all the participating students. In terms of artistic-creative development, we can notice that the students' scores were highest for fluency and lowest for redefinition. In terms of artisticappreciative abilities, the scores for questions pertaining to the perceptive skills were highest for the item "In which part of the painting are the colours the strongest?" and lowest for the item "Which two colours are the most important in the painting?" The scores for questions pertaining to the students' receptive abilities were highest for the item "How would you feel in the room with the vase?" and 
lowest for the item "The beauty and the freshness of the flowers give the impression of...”.

Analysing individual items according to gender showed significant statistical differences for the following items: "fluency" $\left(\chi^{2}=7.177, \mathrm{df}=4, \mathrm{p}=0.049\right)$, where the average score for the boys $(\mathrm{M}=4.35, \mathrm{SD}=2.12)$ was lower than that for the girls $(M=4.61, S D=1.97)$; "redefinition" $\left(\chi^{2}=5.738, \mathrm{df}=3, \mathrm{p}=0.053\right)$, where the average score for the boys $(\mathrm{M}=0.53, \mathrm{SD}=1.01)$ was lower than that for the girls $(\mathrm{M}=0.89, \mathrm{SD}=1.02)$ and "elaboration" $\left(\chi^{2}=16.363, \mathrm{df}=4, \mathrm{p}=0.001\right)$, where the average score for the boys $(\mathrm{M}=3.00, \mathrm{SD}=1.46)$ was lower than that for the girls $(\mathrm{M}=4.33, \mathrm{SD}=0.59)$.

The data reveals that the students' average scores were roughly halved compared to the total score. Analysing the data according to gender showed higher average scores for the girls than for the boys. Higher achievements of the girls could be ascribed to the greater manoeuvrability and concentration on schoolwork of the girls during adolescence. Higher fluency and success of redefinition could be attributed to conscientious planning of the process work or art elaboration.

\section{The gifted vs. the non-gifted students' creativity levels}

In this research, we were interested in comparing the achievements of the gifted and the non-gifted students in the art creativity and art appreciation tests. Also, we wanted to know whether gender differences might occur. The results are shown in Table 4.

As can be seen in Table 4, the gifted students' scores in artistic-creative development were highest in "fluency" and lowest in "redefinition". Their scores in perceptive skills were highest for the item "In which part of the painting are the colours the strongest?" and lowest for the item "Which two colours are the most important in the painting?", whereas their scores in receptive skills were highest for the item "How would you feel in the room with the vase?" and lowest for the item "The beauty and freshness of the flowers give the impression of...". Analysing their scores according to gender showed significant statistical differences for the item "elaboration" ( $\left.\chi^{2}=8.571, \mathrm{df}=4, \mathrm{p}=0.028\right)$, where the boys' $(\mathrm{M}=2.40, \mathrm{SD}=1.52)$ average scores were lower than the girls' ones $(\mathrm{M}=4.29, \mathrm{SD}=0.49)$.

Furthermore, we were interested in the achievements of the non-gifted students' results of the art creativity and art appreciation tests. We wanted to know whether gender differences occur in this part of the research, as well. The results are displayed in Table 5.

In Table 5, we can see the scores of the non-gifted students. The non-gifted students' scores in artistic-creative development were highest in "fluency" and 
Table 4. Means and standard deviations of the gifted $(\mathrm{N}=12)$ students' creativity levels

\begin{tabular}{|c|c|c|c|c|c|c|c|}
\hline & \multirow[t]{2}{*}{ Item } & $\begin{array}{c}\text { Means } \\
\text { all } \\
(N=12)\end{array}$ & $\begin{array}{c}\text { Standard } \\
\text { deviation } \\
\text { all }\end{array}$ & $\begin{array}{c}\text { Means } \\
\text { boys } \\
(N=5)\end{array}$ & $\begin{array}{c}\text { Standard } \\
\text { deviation } \\
\text { boys }\end{array}$ & $\begin{array}{c}\text { Means } \\
\text { girls } \\
(N=7)\end{array}$ & $\begin{array}{c}\text { Standard } \\
\text { deviation } \\
\text { girls }\end{array}$ \\
\hline & & $M$ & $S D$ & $M$ & $S D$ & $M$ & $S D$ \\
\hline \multirow{6}{*}{ 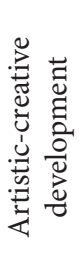 } & 1. Fx & 1.67 & 1.67 & 1.40 & 1.52 & 1.86 & 1.86 \\
\hline & 2. $\mathrm{Fl}$ & 4.58 & 1.83 & 4.80 & 1.64 & 4.43 & 2.07 \\
\hline & 3. Or & 1.42 & 0.79 & 1.40 & 0.89 & 1.43 & 0.79 \\
\hline & 4. $\operatorname{Re}$ & 1.08 & 1.08 & 0.80 & 1.30 & 1.29 & 0.95 \\
\hline & 5. $\mathrm{Sp}$ & 2.33 & 0.89 & 2.00 & 0.71 & 2.57 & 0.98 \\
\hline & 6. El & 3.50 & 1.38 & 2.40 & 1.52 & 4.29 & 0.49 \\
\hline \multirow{8}{*}{ 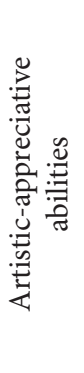 } & 7.P1 & 2.42 & 0.90 & 2.60 & 0.89 & 2.29 & 0.95 \\
\hline & 8. P2 & 1.75 & 0.62 & 1.80 & 0.45 & 1.71 & 0.76 \\
\hline & 9. P3 & 2.92 & 1.62 & 2.80 & 1.64 & 3.00 & 1.73 \\
\hline & 10. P4 & 2.42 & 1.73 & 3.00 & 1.41 & 2.00 & 1.91 \\
\hline & 11. R1 & 2.17 & 1.34 & 1.80 & 1.64 & 2.43 & 1.13 \\
\hline & 12. R2 & 1.25 & 1.55 & 1.80 & 1.64 & 0.86 & 1.46 \\
\hline & 13. R3 & 2.75 & 0.87 & 2.40 & 1.34 & 3.00 & 0.00 \\
\hline & $14 . \mathrm{K}$ & 1.75 & 1.55 & 1.20 & 1.64 & 2.14 & 1.46 \\
\hline \multicolumn{2}{|c|}{ Group average } & 2.29 & 1.27 & 2.16 & 1.30 & 2.38 & 1.18 \\
\hline
\end{tabular}

lowest in "redefinition". Their scores in perceptive skills were highest for the item "In which part of the painting are the colours the strongest?" and lowest for the item "Is there anything you would add to the painting?" Their scores in receptive skills were highest for the item "How would you feel in the room with the vase?" and lowest for the item "The beauty and freshness of the flowers give the impression of..... Analysing their scores according to gender showed significant statistical differences for the item "elaboration" $\left(\chi^{2}=8.711, \mathrm{df}=4, \mathrm{p}=0.039\right)$, where the boys' $(M=3.25, S D=1.42)$ average scores were lower than the girls' ones $(M=4.36$, $\mathrm{SD}=0.37)$.

Data analysis reveals that the gifted students were more successful in gaining a higher average score on the test, as well as the majority of individual items in the test. However, the non-gifted students scored higher in the last item of the test "What are the basic artistic means in painting?", which was the only item assessing the students' knowledge. This may indicate that the non-gifted students may be less creative but they learn about art; on the other hand the gifted students might be 
Table 5. Means and standard deviations of the non-gifted students' creativity levels $(\mathrm{N}=23)$

\begin{tabular}{|c|c|c|c|c|c|c|c|}
\hline & Item & $\begin{array}{c}\text { Means } \\
\text { all } \\
(N=23)\end{array}$ & $\begin{array}{c}\text { Standard } \\
\text { deviation } \\
\text { all }\end{array}$ & $\begin{array}{c}\text { Means } \\
\text { boys } \\
(N=12)\end{array}$ & $\begin{array}{c}\text { Standard } \\
\text { deviation } \\
\text { boys }\end{array}$ & $\begin{array}{c}\text { Means } \\
\text { girls } \\
(N=11)\end{array}$ & $\begin{array}{c}\text { Standard } \\
\text { deviation } \\
\text { girls }\end{array}$ \\
\hline & & $M$ & $S D$ & $M$ & $S D$ & $M$ & $S D$ \\
\hline \multirow{6}{*}{ 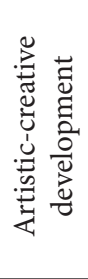 } & 1. $\mathrm{Fx}$ & 1.26 & 1.51 & 1.17 & 1.53 & 1.36 & 1.57 \\
\hline & 2. $\mathrm{Fl}$ & 4.47 & 2.15 & 4.17 & 2.33 & 4.73 & 2.00 \\
\hline & 3. Or & 1.35 & 0.72 & 1.33 & 0.78 & 1.36 & 0.67 \\
\hline & 4. $\operatorname{Re}$ & 0.52 & 0.95 & 0.42 & 0.90 & 0.64 & 1.03 \\
\hline & 5. $\mathrm{Sp}$ & 1.61 & 1.20 & 1.42 & 1.08 & 1.82 & 1.33 \\
\hline & 6. El & 3.78 & 1.24 & 3.25 & 1.42 & 4.36 & 0.67 \\
\hline \multirow{8}{*}{ 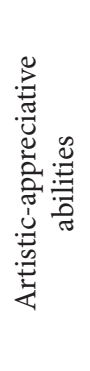 } & 7.P1 & 2.74 & 0.69 & 2.83 & 0.58 & 2.64 & 0.81 \\
\hline & 8. P2 & 1.70 & 0.56 & 1.50 & 0.67 & 1.91 & 0.30 \\
\hline & 9. P3 & 2.96 & 1.46 & 3.25 & 1.36 & 2.64 & 1.57 \\
\hline & 10. P4 & 1.61 & 1.73 & 1.17 & 1.53 & 2.09 & 1.87 \\
\hline & 11. R1 & 2.13 & 1.14 & 2.08 & 1.16 & 2.18 & 1.17 \\
\hline & 12. R2 & 0.78 & 1.35 & 1.00 & 1.48 & 0.55 & 1.21 \\
\hline & 13. R3 & 2.39 & 1.08 & 2.58 & 1.00 & 2.18 & 1.17 \\
\hline & 14. K & 2.09 & 1.41 & 2.00 & 1.48 & 2.18 & 1.40 \\
\hline \multicolumn{2}{|c|}{ Group average } & 2.10 & 1.23 & 2.01 & 1.24 & 2.19 & 1.20 \\
\hline
\end{tabular}

inherently more creative, but do not pay attention to learning about art in school. The difference between the gifted and the non-gifted students was the highest for the item "Is there anything you would add to the painting?" $(\Delta \mathrm{M}=0.81)$ and the lowest for the variable "In which part of the painting are the colours the strongest?" $(\Delta \mathrm{M}=0.04)$. Analysing the data according to gender revealed that the girls' average scores were higher than the boys' for both the gifted and the non-gifted students.

\section{Creativity levels among the gifted students according to the type of giftedness}

The gifted students' scores were analysed according to the type of giftedness. Table 6 shows the gifted students' scores in individual items. The general creativity levels were the highest for the student who was recognized as gifted in music $(\mathrm{M}=2.71, \mathrm{SD}=/)$. The creativity levels were the lowest for the students who were 


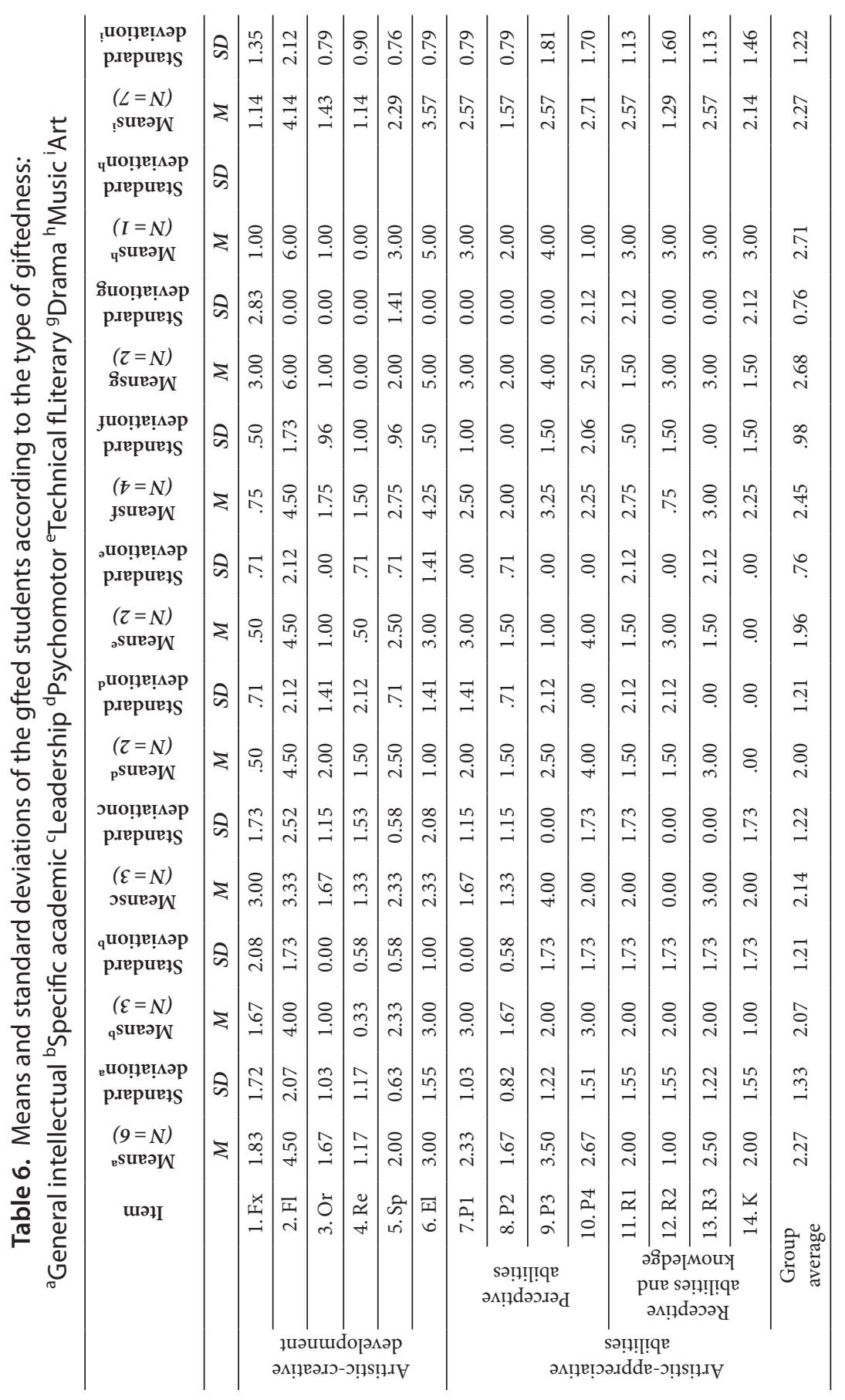


recognized as gifted in the technical field $(M=1.96, S D=0.76)$. Statistically significant differences according to gender were detected for the item "redefinition" $\left(\chi^{2}=4.958, \mathrm{df}=2, \mathrm{p}=0.034\right)$, where the boys' $(\mathrm{M}=0.33, \mathrm{SD}=0.58)$ average score was lower than the girls' $(\mathrm{M}=1.75, \mathrm{SD}=0.50)$.

Our research suggests that the individuals who were identified as gifted based on their high IQ were ranked $3^{\text {rd }}$ most successful according to their average LV1Test score $(\mathrm{M}=2.27, \mathrm{SD}=1.33)$. Their average score was equal to that of the artistically gifted students $(\mathrm{M}=2.27, \mathrm{SD}=1.22)$; it was surpassed by the average scores of the literary gifted students $(\mathrm{M}=2.45, \mathrm{SD}=0.98)$, students gifted in drama $(\mathrm{M}=2.68, \mathrm{SD}=0.76)$ and the musically gifted $(\mathrm{M}=2.71, \mathrm{SD}=/)$. We can conclude that in this group of participants, creative thinking was not more prominent for high-IQ students.

\section{Conclusions}

The research firstly aimed at establishing the general levels of creativity among the gifted and non-gifted students of elementary schools in the Posavje region, Slovenia (RQ1). Using the LV 1 Test instrument, we were able to establish the average creativity levels of all the participating students, which were below the test average. We also found that the girls' average scores were higher than the boys'. The existing data on gender roles in measuring creativity has either not shown gender differences in creativity (Kaufman, 2006; Kogan, 1974) or shown that males are more successful in creativity tests (Stolitzfus, Nibbelink, Vredenburg and Thyrum, 2011; He and Wong, 2011). Our research findings reveal the opposite, with the girls being more successful in creativity tests. We then separately analysed the scores for the gifted (RQ2) and the non-gifted students (RQ3). The gifted students' average score was higher than that of the non-gifted students. The girls proceeded to achieve a higher average score in both groups of students. These findings are in accordance to previous research in this field (Terman and Oden, 1947; Houtz, Rosenfield and Tetenbaum, 1978). Lastly, we analysed the gifted students' scores according to the different types of giftedness they were ascribed to by their teachers (RQ4). The data revealed that none of the gifted students reached the LV1 Test average score - in fact, most of them were well below. The students who were gifted on the basis of their general intellectual skills also failed to show high creativity levels, as can be, surprisingly, said for artistically gifted students. The best score was obtained by a musically gifted student, whereas the score was the lowest for the group of technically gifted students. Our research revealed data which are contrary 
to the findings of previous research in this field (Guilford and Christiansen, 1973; Torrance, 1980; Getzels and Jackson, 1962; Wallach and Kogan, 1965). The sample included students who were recognized as gifted in visual arts by their teachers (RQ5). The results show that these students did not achieve above-average scores in the LV1 Test and therefore did not stand out in terms of their creativity levels.

Such results are worrying - one would expect gifted students to show higher levels of creativity, at least the students gifted in technical, artistic or general intellectual areas. The research findings may indicate a lack of creative teaching among the participating students, as well as the teachers' inability to recognize creative students.

\section{References}

Berce-Golob, H., (1990). Metode likovno vzgojnega dela v osnovni šoli na področju slikarstva (Unpublished doctoral dissertation). Ljubljana, ALU.

Craft, A. (2005). Creativity in schools: Tensions and dilemmas. London: Routlege.

Davies, T. (2006). Creative teaching and learning in Europe: promoting a new paradigm. The Curriculum Journal, 17 (1), 37-57.

Duh, M. (2004). Vrednotenje kot didaktični problem pri likovni vzgoji. Maribor: Univerza v Mariboru, Pedagoška fakulteta.

Duh, M., Čagran, B. \& Huzjak, M. (2012). Quality and quantity of teaching art appreciation. Croatian Journal of Education, 14 (3), 625-655.

Duh, M., Zupančič, T. \& Čagran, B. (2014). Development of art appreciation in 11-14 yearold students. International Journal of ArtઐDesign Education, 33, 208-222.

Duh, M., Korošec, A. (2014). The development of art appreciation abilities of pupils in primary school. The new educational review, 36 (2), 42-54.

Feldhusen, J.F. \& Hoover, S.M. (1986). A conception of giftedness: intelligence, self-concept and motivation. Roeper Review, 8 (3), 140-143.

Fryer, M. (2009, May, 28-29). "Promoting creativity in education and the role of measurment". Paper presented at the Can creativity be measured? Conference, Brussels. Luxembourg: Publications Office of the European Union.

Gagné, F. (1991). Brief presentation of Gagné and Nadeau's attitude scale: Opinions about the gifted and their education. Montreal: University of Québec.

Getzels, J.W. \& Jackson, P.W. (1962). Creativity and intelligence. New York: Wiley.

Guilford, J.P. \& Christensen, P.R. (1973). The one-way relation between creative potential and IQ. Journal of creative behaviour, 7, 247-252.

He, W., \& Wong, W. (2011). Gender differences in creative thinking revisited: Findings from analysis of variability. Personality \& Individual Differences, 51 (7), 807-811.

Hitt, W.D. (1965). Toward a two-factor theory of creativity. Psychological Record, 15, 127-132 Houtz, J.C., Rosenfield, S. \& Tetenbaum, T.J. (1978). Creative thinking in gifted elementary schoolchildren. Gifted Child Quarterly, 22, 513-519. 
Jeffrey, B. (2006). Creative teaching and learning: towards a common discourse and practice. Cambridge Journal of Education, 36 (3), 399-414.

Juriševič, M. (2011). Nadarjeni učenci v slovenski šoli. Ljubljana: Pedagoška fakulteta univerze v Ljubljani.

Jurman, M. (2004). Inteligentnost, ustvarjalnost, nadarjenost. Ljubljana: Center za psihologijo.

Karlavaris, B., and Kraguljac, M. (1970). Estetsko procenjivanje u osnovnoj školi. Beograd, Umetnička akademija.

Kaufman, J.C. (2006). Self-reported differences in creativity by ethnicity and gender. Applied Cognitive Psychology, 20 (1), 1065-1082.

Koestler, A. (1964). The act of creation. London: Macmillan.

Kogan, N. (1974). Creativity and sex differences. The Journal of Creative Behavior, 8 (1), 1-14.

Matrić, M. \& Košir, K. (2014). Perceived autonomy levels among elementary school students and their teachers. The New Educational Review, 37 (3), 215-228.

Mumford, M.D., Mobley, M.I., Uhlman, C.E., Reiter-Palmon, R. \& Doares L.M. (1991). Process analytic models of creative thought. Creative Research Journal, 4, 91-122.

Newell, A. \& Shaw, J.C. (1972. The process of creative thinking. In A. Newell \& H.A. Simon (Eds), Human Problem Solving (114-174). Prentice Hall, Englewood Cliffs, NJ.

Robinson, K. (2001). Out of our minds: Learning to be creative. Oxford: Capstone.

Sefton-Green, J. \& Sinker, R. (2000). Evaluating creativity: Making and learning by young people. London: Routlege.

Sharp, C. and Le Métais, J. (2000). The Arts, Creativity and Cultural Education: an International Perspective (International Review of Curriculum and Assessment Frameworks). London: QCA.

Stables, K. (2009). Educating for environmental sustainability and educating for creativity: actively compatible or missed opportunities? International Journal of Technology and Design Education, 19, 199-219.

Stolitzfus, G., Nibbelink, B., Vredenburg, D. \& Thyrum, E. (2011). Gender, gender role, and creativity. Social Behavior \& Personality: An International Journal, 39 (3), 425-432.

Terman, L.M., Oden, M.H. \& Bailey, M. (1947). The gifted child grows up: Twenty-five years' follow-up of a superior group. Stanford, CA: Stanford University Press.

Torrance, E.P. (1959). Explorations in creative thinking in the early school years: A progress report. In C.W. Taylor (Ed.). The third University of Utah research conference on the identification of creative scientific talent (58-71). Salt Lake City: University of Utah.

Torrance, E.P. (1977). Discovery and nurturance of giftedness in the culturally different. Reston, VA: Council on Exceptional Children.

Torrance, E.P. (1980). Creative intelligence and "an agenda for the 80's" Art Education, 33, 8-14.

Ulmann, G. (1968). Kreativität: Neue amerikanische Ansätze zur Erweiterung des Intelligenzkonzeptes. Weinheim: Beltz.

Wallach, M.A. \& Kogan, N. (1965). Modes of thinking in young children. New York: Holt, Rinehart \& Winston. 